\title{
E-MODUL PEMBELAJARAN MATERI PEMANASAN GLOBAL BERBASIS QUANTUM LEARNING
}

\author{
Zahra Qibtia Balqis ${ }^{\text {a) }}$, Sunaryo ${ }^{\text {b) }}$, Esmar Budi \\ Program Studi Pendidikan Fisika, Fakultas Matematika dan Ilmu Pengetahuan Alam, Universitas Negeri \\ Jakarta, Jl. Rawamangun Muka No.1, Jakarta Timur \\ Email: ${ }^{\text {a) }}$ zaqibalqis@gmail.com,, b) naryounj@yahoo.co.id
}

\begin{abstract}
Abstrak
Penelitian ini bertujuan untuk mengembangkan modul elektronik fisika materi Pemanasan Global berbasis Quantum Learning. Penelitian ini menggunakan metode ADDIE dengan tahapan 1) Analyze, 2) Design, 3) Development, 4) Implementation, dan 5) Evaluation. E-modul ini menerapkan rumus AMBAK (Apa Manfaat Bagiku) yang terdapat dalam model pembelajaran Quantum Learning. Pengembangan e-modul ini memperoleh data dari angket uji validasi dan angket uji kelayakan media. Hasil kajian pendahuluan menyatakan bahwa E-Modul pembelajaran ini cukup layak dijadikan modul belajar.
\end{abstract}

Kata-kata kunci: E-modul Fisika, Quantum Learning, Pemanasan Global.

\begin{abstract}
This research is aimed to develop a physics electronic modules about Global Warming based on Quantum Learning. This research using the ADDIE method with stages 1) Analyze, 2) Design, 3) Development, 4) Implementation, and 5) Evaluation. This e-module applies the AMBAK formula (Apa Manfaat Bagiku or What are the Benefits to Me) contained in the Quantum Learning model. E-module Development obtains data from the validation test questionnaire and media feasibility questionnaire. Preliminary test result state that this learning e-module is decent enough to be created as. learning module.
\end{abstract}

Keywords: Physics E-module, Quantum Learning, Global Warming.

\section{PENDAHULUAN}

Didalam fisika, kita mempelajari gejala-gejala benda-alam, baik yang terjadi pada benda (materi) yang dapat diamati, maupun benda yang tidak dapat diamati (mikro) [1]. Mata pelajaran Fisika menjelaskan seluruh fenomena yang terjadi di alam ini, sehingga masalah-masalah yang berhubungan dengan Fisika kerap kita jumpai dalam kehidupan sehari-hari. 
Fakta di lapangan, pembelajaran Fisika hanya sekadar pemberian materi tanpa melibatkan peserta didik dalam pembelajaran. Pembelajaran Fisika akan lebih bermakna ketika peserta didik terlibat terutama dalam hal berpikir. Pembelajaran juga akan bermakna bila dikaitkan dengan dunia nyata yang disajikan secara kontekstual sehingga peserta didik mampu memahami dan menerapkan konsep dalam kehidupan sehari-hari [2].

Salah satu komponen penting untuk mendukung keberhasilan pembelajaran Fisika adalah bahan ajar. Berdasarkan hasil pengamatan dan kuisioner, dalam pembelajaran Fisika di sekolah siswa hanya menggunakan buku paket yang dipinjamkan sekolah., dan siswa merasa belum cukup mengerti hanya dengan menggunakan buku tersebut.

Salah satu bahan ajar yang dapat digunakan siswa untuk belajar mandiri adalah dalam bentuk modul [3]. Modul merupakan bahan ajar yang dapat digunakan oleh siswa untuk belajar secara mandiri dengan bantuan seminimal mungkin dari orang lain [4]. Melalui modul, guru dapat memadukan beberapa kompetensi dasar menjadi sebuah tema. Tema yang dipilih oleh guru dapat disesuaikan dengan perkembangan kognitif siswa dan disesuaikan dengan lingkungan sekitar siswa [5].

Kemajuan teknologi merupakan salah satu faktor pendukung dalam proses belajar siswa .Akhirakhir ini modul cetak sudah jarang ditemukan, karena siswa lebih memilih melihat materi melaui ponsel ketimbang buku cetak atau modul cetak, oleh karena itu E-modul lahir sebagai hasil dari bahan ajar yang terintegrasi dengan kemajuan teknologi. Kendala penggunaan bahan ajar modul adalah sulitnya menarik perhatian Siswa untuk menggunakan modul dalam belajar. Hal tersebut karena kurang menariknya penampilan, isi, maupun penyampaian gagasan materi dalam suatu modul. Apalagi jika Siswa belum mengetahui cara dan gaya belajar yang baik dan sesuai dengan dirinya [6]. DePorter dan Hernacki dalam buku quantum learning (2008: 110), cara dan gaya belajar merupakan kunci untuk mengembangkan kinerja seseorang termasuk Siswa di sekolah.

Quantum learning mencakup aspek-aspek penting dalam program neurolinguistik (NLP), yaitu suatu penelitian tentang bagaimana otak mengatur informasi [7]. Dalam quantum learning, belajar fisika bukan hanya sebatas mempelajari secara teoritis yang bersifat hafalan saja, tetapi lebih ditekankan pada penerapan-penerapan ilmu fisika dalam kehidupan sehari-hari. Oleh karena itu, guru dituntut untuk selain memahami materi fisika juga perlu mengetahui keterkaitan materi tersebut dengan kehidupan sehari-hari, berupa penerapan dalam bidang teknologi dan juga dampak bagi lingkungan maupun sosial masyarakat.

Salah satu materi yang ada didalam fisika SMA dan sangat berkaitan erat dengan lingkungan dan kehidupan sehari-hari yaitu, materi Pemanasan Global, dimana siswa harus mengetahui gejala dampak dan alternatif solusi energi dari pemanasan global. Untuk mengetahui tiga hal tersebut maka siswa diharapkan dapat mempeloreh dengan lima cara pembelajaran, yaitu: mengamati, menanyanyakan, mengeksplorasi, mengasosiasi serta mengomunikasikan.

Oleh karena itu, penulis terdorong untuk mengembangkan E-modul pembelajaran materi Pemanasan Global berbasis Quantum Learning. Modul yang dikembangkan merupakan modul elektronik dengan materi Pemanasan Global yang berkaitan dengan kehidupan sehari-hari siswa dengan menggunakan metode Quantum Learning.

\section{METODOLOGI}

Penelitian ini bertujuan untuk mengembangkan E-Modul Pembelajaran Pemanasan Global berbasis Quantum Learning. Metode yang digunakan dalam penelitian ini adalah model penelitian ADDIE. Model ADDIE adalah desain model pembelajaran yang sistematis dan terdiri dari 5 tahap ini meliputi desain keseluruhan proses pembelajaran cara yang sistematik. Dalam penelitian ini penulis membatasi penelitian sampai tahap ke 3 yaitu development (pengembangan).

1. Tahap Analisis 
Pada tahap Pada penelitian ini dilakukan analisis kebutuhan dengan menggunakan studi literatur dan data hasil penelitian lembaga survey. Dalam penelitian ini peneliti mengembangkan E-modul pembelajaran materi Pemanasan Global berbasis Quantum Learning, untuk itu peneliti juga melakukan analisis materi. Materi Pemanasan Global terdapat dalam Kompetensi Dasar Mata Pelajaran Fisika tingkat Sekolah Mengengah Atas.

TABEL 1. Kompetensi Dasar

\begin{tabular}{|c|c|c|}
\hline Kompetensi Inti & Kompetensi Dasar & Indikator Pencapaian Kompetensi \\
\hline 3 & $\begin{array}{lr}3.12 & \text { Menganalisis } \\
\text { gejala pemanasan } \\
\text { global } \\
\text { dampaknya } & \text { dan } \\
\text { kehidupan } & \text { serta } \\
\text { lingkungan. } & \end{array}$ & $\begin{array}{l}\text { 3.12.1 Mengamati dampak } \\
\text { pemanasan global yang didukung oleh } \\
\text { informasi dari berbagai sumber } \\
3.12 .2 \text { Mengamati aktifitas manusia } \\
\text { yang mengakibatkan berbagai dampak } \\
\text { yaitu pada pemanasan global, efek } \\
\text { rumah kaca, dan perubahan iklim } \\
\text { 3.12.3 Menanyakan apa penyebab } \\
\text { dan dampak pemanasan global, efek } \\
\text { rumah kaca, dan perubahan iklim bagi } \\
\text { kehidupan } \\
3.12 .4 \text { Menanyakan bentuk solusi } \\
\text { dan usaha apa yang harus dilakukan } \\
\text { untuk mencegah dampak lebih buruk } \\
\text { dari pemanasan global } \\
\text { 3.12.5 Mengeksplorasi fenomena } \\
\text { pemanasan global, efek rumah kaca, } \\
\text { dan perubahan iklim serta dampak } \\
\text { yang diakibatkan bagi manusia }\end{array}$ \\
\hline 4 & $\begin{array}{l}\text { 4.12 Mengajukan } \\
\text { ide/gagasan } \\
\text { penyelesaian } \\
\text { masalah } \\
\text { pemanasan global } \\
\text { sehubungan } \\
\text { dengan gejala dan } \\
\text { dampaknya bagi } \\
\text { kehidupan serta } \\
\text { lingkungan }\end{array}$ & $\begin{array}{l}\text { 4.12.1 Mendiskusikan hasil-hasil } \\
\text { kesepakatan global IPCC, Protokol } \\
\text { Kyoto, APPCDC, dan lain-lain } \\
\text { melalui berbagai sumber secara } \\
\text { berkelompok } \\
4.12 .2 \text { Mendiskusikan pemecahan } \\
\text { masalah untuk mengurangi dampak } \\
\text { efek rumah kaca, emisi karbon, dan } \\
\text { lain-lain } \\
4.12 .3 \text { Merencanakan berbagai } \\
\text { usulan pemecahan masalah pemanasan } \\
\text { global berdasarkan klasifikasi dan } \\
\text { penyebabnya secara berkelompok } \\
4.12 .4 \text { Membuat laporan dan } \\
\text { presentasi hasil kerja kelompok }\end{array}$ \\
\hline
\end{tabular}

\section{Tahap Desain (Design)}

Pada tahap ini yaitu menyusun E-Modul fisika berbasis Quantum Learning pada materi pemanasan Global. E-Modul yang dibuat mengarahkan siswa untuk memahami konsep fisika dan kaitan dengan lingkungan sekitarnya khususnya pada materi pemanasan global. Dengan menerapkan AMBAK (apa manfaat bagiku) yang ada di Quantum Learning, diharapkan dapat meningkatkan pemahaman konsep fisika siswa sehingga siswa merasa senang dan antusias dalam belajar fisika. Desain produk e-modul ini dihasilkan dari komparasi dengan modul elektronik dari penelitian sebelumnya [8-10].

\section{Tahap pengembangan ( Development)}


Kegiatan dilanjutkan dengan merealisasikan rancangan produk, yaitu membuat E-modul berbasis Quantum Learning yang mengacu pada tahap perancangan produk awal. Pada tahap ini dilakukan dengan cara menguji isi dan keterbacaan modul kepada pakar yang terlibat pada saat validasi.

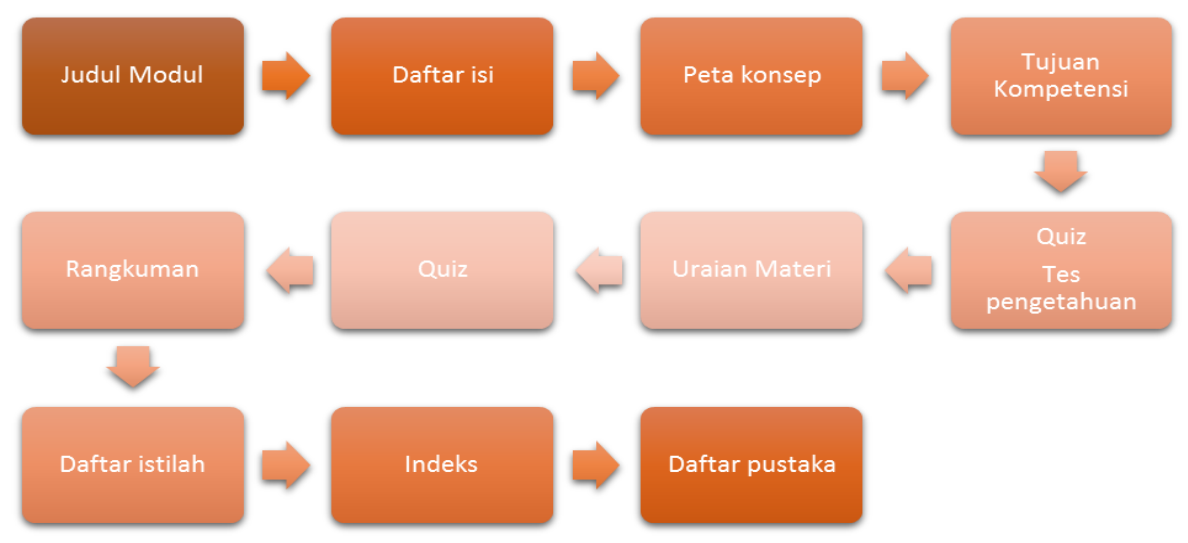

GAMBAR 1. Komponen yang dikembangkan dalam E-Modul Pemanasan Global

\section{HASIL DAN PEMBAHASAN}

Hasil dari penelitian ini berupa modul elektronik dengan materi Pemanasan Global dengan menggunakan metode Quantum Learning yaitu dengan menerapkan rumus AMBAK (apa Manfaat Bagiku). Produk yang dihasilkan dari penelitian ini diharapkan dapat digunakan sebagai sumber belajar bagi siswa SMA sehingga dapat menambah pengetahuan siswa dan dapat melatih kemampuan siswa berpikir dalam memecahkan masalah dari sosal-soal latihan yang ada.

Berikut merupakan tampilan E-Modul yang dikembangkan :

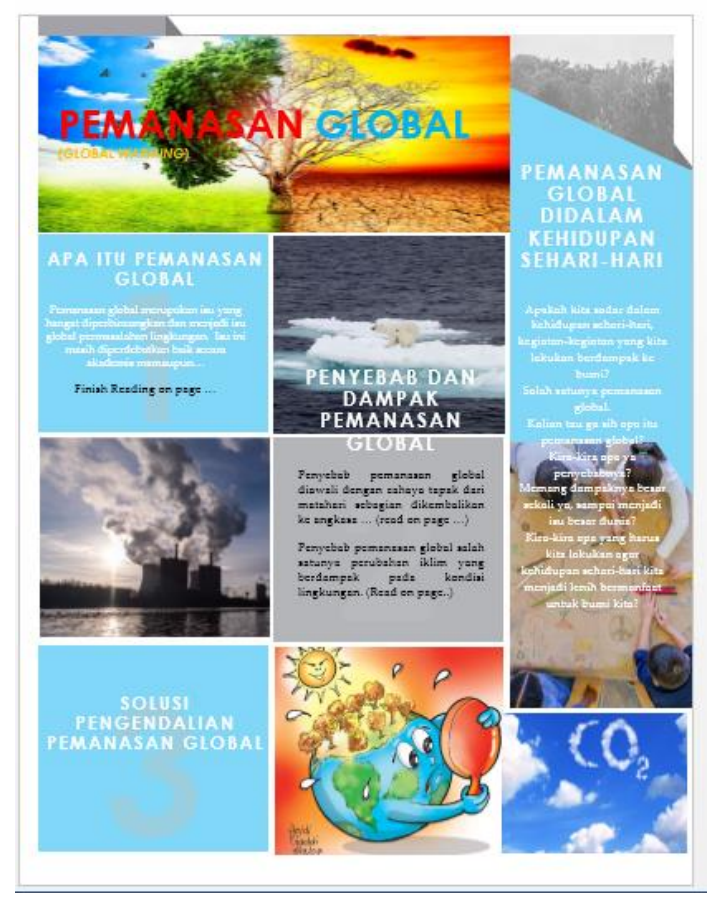


GAMBAR 2. Beberapa tampilan pengembangan E-Modul Pembelajaran berbasis Quantum Learning

\section{SIMPULAN}

Pada penelitian ini dihasilkan produk berupa E-Modul Fisika mengenai pemanasan global untuk siswa SMA. Peneliti berharap dengan adanya E-Modul Pemanasan Global dapat menjadi sumber belajar bagi siswa baik di sekolah maupun di rumah mengingat E-Modul ini dapat diakses melalui smartphone. Semoga penelitian ini bisa dimanfaatkan sebagaimana mestinya dan menjadi inspirasi para pendidik untuk mengembangkan media pembelajaran yang lain.

\section{REFERENSI}

[1] M. Kanginan, Fisika untuk SMA/MA kelas XI, Jakarta: Erlangga, 2013.

[2] T. Amanda, "Pengembangan Modul Pembelajaran Berbasis Multirepresentasi Pada Pembelajaran Fisika Di SMA/MA," Jurnal Universitas Jember, 2017.

[3] Y. Munadi, Media Pembelajaran: Sebuah Pendekatan Baru, Jakarta: Gaung persada Press, 2008.

[4] H. Irawati, "Pengembangan Modul Pembelajaran IPA dengan Tema Pencemaran Lingkungan untuk meningkatkan hasil belajar siswa SMP kelas VII," Jurnal Bioedukatika, 2015.

[5] M. Imaduddin, "Modul Q-Sets" Sebagai Rekayasa Bahan Ajar Kimia Yang Bermuatan Quantum Learning Dan Bervisi Salingtemas," Jurnal Universitas Negeri Semarang, 2013.

[6] W. Borg and M. D. Gall, Education Research An Introduction, New York: Longman, 1983.

[7] F. K. Sari, "Pengembangan Media Pembelajaran (Modul) berbantuan Geogebra Pokok Bahasan Turunan," Al-Jabar: Jurnal Pendidikan Matematika, 2016.

[8] S. Syahrowardi and A. H. Permana, "Desain Handout Multimedia Menggunakan 3D Pageflip Professional untuk Media Pembelajaran pada Sistem Android”, jpppf, vol. 2, no. 1, pp. 89 96, Jun. 2016.

[9] H. Kurniawati, D. Desnita, and S. Siswoyo, "Pengembangan Media Pembelajaran Berbasis 3D PageFlip Fisika untuk Materi Getaran dan Gelombang Bunyi”, jpppf, vol. 2, no. 1, pp. 97 - 102, Jun. 2016.

[10] F. Bakri, B. Z. Siahaan, and A. H. Permana, "Rancangan Website Pembelajaran Terintegrasi dengan Modul Digital Fisika Menggunakan 3D PageFlip Professional”, jpppf, vol. 2, no. 2, pp. 113 - 118, Dec. 2016. 
